\title{
A Documentation Review of Yoruba Indigenous Architectural Morphology
}

\author{
ADENAIKE, Folahan Anthony \\ Department of Architectural Technology, Lagos State Polytechnic, Ikorodo, Lagos State. Department of \\ Architecture, School of Science and Technology, Covenant University, Otta, Nigeria \\ OPOKO, Akunnaya Pearl \\ Department of Architecture, School of Science and Technology, Covenant University, Otta, Nigeria \\ OLADUNJOYE, Kolawole G. K. \\ Department of Architectural Technology, The Polytechnic, Ibadan, Nigeria
}

\begin{abstract}
The indigenous architecture of the Yoruba which is the summation of the traditional, the vernacular and the contemporary ethno-acculturation of contemporary styles has not received a robust level of reporting from recent publications. This study was carried out with the sole aim of organizing the various lines of thought into a continuum for defining the evolution of the Yoruba architecture in the simplest way. A search was conducted in the Social Science Citations Index and Google Scholar to sift out the publications with "Yoruba Architecture" and "Southwest Nigeria Architecture" as search words. Thirty relevant publications of the sixty-seven publications that related to the topic among others were selected for further scrutiny. It was discovered that most of the publications were descriptive and eclectic in their analysis. They sought to explain the architecture basically as a spatial product of the socio-cultural demands of the society. The traditional and vernacular styles are well documented and easily explained by this approach. There was however very little attempt to decipher the current threshold of the indigenous architecture in the face of the overwhelming influence of the postmodern and contemporary building styles that are common in Yoruba towns of recent.
\end{abstract}

Keywords: International style, post vernacular architecture, postmodern architecture, traditional architecture, vernacular architecture, thresholds.

DOI: $10.7176 / \mathrm{JAAS} / 66-05$

Publication date:July $31^{\text {st }} 2020$

\section{INTRODUCTION}

Recent global issues in the likes of conservation, climate change, sustainability and environmental pollution have infiltrated most fields of academic pursuit. Urban studies provide inroads to a large proportion of researchable entities relevant to current global challenges. Architectural morphology is an intricate endeavor within the field of urban studies. In essence, architecture is the science of spatial technocracy. It prescribes the definition of spaces, objects and forms within the environment. Architects as space technocrats use services and building materials to address the basic programme of space definition and function (Gharibpour, 2012). The architecture of a place is defined by the culture of the resident people (Mihaila.2014). Architecture when it relates to a particular place describes the street design, the landscape, the buildings and the public spaces. In this study, the buildings and their clusters will be the zones of concentration. Of particular importance is the architectural building morphology of the area in question. The architectural morphology of buildings and clusters is a continuum of discursive processes in maintenance, building production and design concepts. The processes are informed by an interplay of the micro climate, the local economy, legislative imperatives, the history of the people and the changing socio-cultural preferences. At the end of architectural building morphological discourse, there may be need to define architectural styles and typologies. Architectural typologies and styles are usually tied to formal or aesthetic representations of a movement which may be cultural or philosophical. Some movements that have been defined in morphological discourses include futurism, brutalism, cubism, postmodernism and deconstruction. They are usually defined around indigenous patterns, vernacular traditions, classical styles, and contemporary architectural styles (Relph, 2016). Their definitions also tend to reflect the socio-cultural and political influences associated with the place and time.

The traditional architecture of the Yoruba of West Africa is fairly consistent throughout the geographical spread (Adedokun, 2014). The land area occupied by the Yoruba starts from Benin Republic and covers the whole of the land mass south of The Sudan eastwards towards the Niger River. The spread includes the southern parts of Benin Republic and the whole of Southwest Nigeria. While the study is targeted at the Yoruba, literature confirms that the whole of West Africa to Central Africa, south of The Sudan is homogenous in traditional architecture (Denyer, 1978; Omokhodion, 1988; Asomani-Boateng, 2011). The homogeneity of the traditional architecture is easily explained as a basic response to the environment and weather elements (Oliver, 2007) that are consistent in 
the West African sub-continent. The vernacular architecture of the Yoruba is however peculiar to them as a whole because vernacular influences on cultures differ from place to place. The vernacular traditions of the Yoruba of Nigeria may be slightly different from what obtained in Yoruba speaking Benin Republic (Asiwaju, 1979) due to the French guild system that influenced the local culture of the Beninoise. The Yoruba of Southwest Nigeria are more cohesive in tradition among themselves than with the Yoruba of Benin Republic. There are geographical and dialectic barriers between the two sub-groups. The vernacular architecture of the whole ethnic group can however be aggregated to dovetail into an identity for their common socio-cultural evolution. The post-vernacular or contemporary architecture of the group needs to be defined in terms of the indigenous patterns that are relevant to the culture of the people. For clarity, it is necessary to differentiate between vernacular and traditional architecture for the purpose of this study. Traditional architecture is the response of the initial and basic culture of a particular people in the organization of their living spaces, materials and their built forms. The vernacular architecture refers to the outcome of combining foreign expertise and materials to the traditional architecture to achieve improved forms and craftsmanship without altering the basic socio-cultural functions of the traditional architecture. In the present age of globalization, there is a lot of cross pollination of cultures. Where such cultural transfers affect the architecture to a large extent, the outcomes cannot be described as traditional or vernacular. The term "indigenous architecture" is a general term that describes architecture that is culture specific. It encompasses the traditional architecture, the vernacular architecture and the subsequent architecture that retain the identity of a culture even where they have imbibed forms, processes and materials from other cultures. Modern architecture popularly known as the "international style" was introduced to Southwest Nigeria in the 1940s. It did not fit into the traditional and vernacular residential patterns of the period. Institutional buildings of the 1950s up to the 1980s were designed following the principles of the style. It was however assimilated into local derivatives which can still be considered as indigenous architecture (Hess, 2006; Uduku, 2006).

\section{TRADITIONAL ARCHITECTURE OF THE YORUBA}

A large cluster of the authors on Yoruba architecture described and explained the traditional building and spatial organisation patterns of the group. The basic building unit which is a single room with a single door and a small window built with mud and forest materials has been identified as the universal module for their traditional buildings (Vlach, 1976; Asomani-Boateng, 2011;). The descriptive essays published about Yoruba traditional architecture are by both local and foreign researchers. They all identified the basic units for most living houses commonly referred to as the "bush house" as a single entity and within the configurative pattern of the larger family compound (Vlach, 1976; Denyer, 1978; Dmochowski, 1990; Osasona, 2007, Asomani-Boateng, 2011). The progression from the bush house is the family compound. The basic dimensions and configuration of the bush house were repeated as additional units to form the family compound. The attributes of these family compounds like the courtyards, impluvia and segregated spaces were points of concentration for other publications that dwelt on the traditional architecture (Osasona and Hyland, 2006; Ilesanmi and Egbe, 2013; Opoko, 2001; Olotuah and Ajenifujah, 2009; Adeokun, 2012) though the concepts especially courtyards were not limited to the traditional forms. The publications also dwelt on certain materials that were commonly used in achieving the forms. These materials and forms were prevalent throughout the study area (Atolagbe, 1996). The monumental structures were however upgraded, based on their levels of importance. The homes of area chiefs, palaces and shrines were adorned with elaborate ornamentation and more spaces within ordered hierarchies (Asomani-Boateng, 2011; Opoko, 2014; Opoko, Adeokun and Oluwatayo, 2016). Another cluster of publications concentrated on the art forms with their social and their semiotic implications (Osasona and Ewemade 2010; Opoko, Adeokun and Oluwatayo, 2016; Atolagbe, 1996). The publications that dealt with Yoruba traditional architecture always delved into the realms of vernacularisation of the traditional architecture as a continuum within the same sphere of traditional buildings except in a few publications where distinctions were made between the traditional and vernacular building patterns (Vlach, 1984; Amole, 2000; Osasona, 2007; Osasona and Ewemade, 2010; Osasona, 2012). With the distinctions, identities can now be defined for the traditional architecture and the vernacular architecture. Because the buildings and clusters of the traditional architecture were repeated in form organization, some writers did not credit the style as an architecture because the consciousness of design was not present at the time of erecting them (Amole, 2000; Blier, 2006). They considered them to the responses to the climatic elements in trial and error so people just continued with what was most efficient within their technological exposure without designing conscious spaces and forms. At best, they are likened to folk architecture as expressed in some other publications (Noble, 2007)

\section{VERNACULAR ARCHITECTURE OF THE YORUBA}

Vernacular architecture of the Yoruba has undergone more robust analysis and publications than the traditional architecture. This may be due to the emergence of design consciousness in the output of the building culture and the development of more complex structures that need more analysis. The publications did not differentiate between the vernacular and traditional architectures and tend to overlap the two concepts in favour of the vernacular structures. The defining factor for placing the discourses under vernacular architecture is the mention 
of the vernacularisation processes in the texts. These were considered as part of the morphologic processes of the traditional architecture when they could have already entered the vernacular tradition (Marafatto, 1983; Valch, 1984; Amole, 2000; Obot, 2007; Osasona, 2007). Beyond the architectural building morphology, significant vernacular buildings in the region are also the subject matter of many publications (Adeniran and Fadamiro, 2011; Umoru-Oke, 2010; Adeokun, 2013). The high point in the publications is the identification of the Afro-Brazilian architecture as a threshold of the vernacular tradition (Vlach, 1984: Alonge and Telford, 1994: Opoko et al, 2016; Osasona, 2007; Osasona and Ewemade, 2010: Arenibafo, 2016). The Afro-Brazilian derivative of the vernacular architecture of Southwest Nigeria was an endpoint. It was never discussed as transforming to other variants of the vernacular architecture. The evolution of Yoruba architecture is hardly discussed as a concept beyond the AfroBrazilian style. The modern and postmodern styles exist in Southwest Nigeria as styles of the post Afro-Brazilian architectural age and are discussed but not as styles borne out of ethno-acculturation by the Yoruba.

\section{POST VERNACULAR ARCHITECTURE OF THE YORUBA}

Beyond the vernacular styles, the major type of architecture that enjoys publication with writers on Southwest Nigeria is modern architecture, popularly referred to as the "international style". The international style is discussed as a foreign intervention in the building design landscape. The style evolved in the 1920s in Central Europe. It was a conscious effort to depart from the eclectic styles of the past and achieve a truly modern type of building pattern. It achieved a stable form of presentation in the early 1950s having evolved through influences from contributions from all over the developed world. Simple geometrical forms, free floor plans, absence of decoration and parapet walls around flat roofs are the basic concepts that formed the essence of the style. Other concepts like the "pilotis" were not heavily emphasized in the style as it matured. It made a landfall in Western Nigeria in the 1950s. Authors of the architecture of Western Nigeria viewed the style as unsuitable for the Nigerian culture and climate (Ogunsote and Prucnal-Ogunsote, 2002; Le Roux, 2004). The advent of the style in Western Nigeria coincided with the building of the first series of high rise buildings in the area which were subsequently designed in the international style (Uduku, 2006). It also found expression in institutional buildings around the area (Roux, 2004). In its original form, it was impersonal and defied the culture of the Yoruba (Prucnal Ogunsote, 2002). The residential buildings which form the greater repository of the indigenous architecture of the Yoruba could not assimilate the new style without adjustments. Although the culture of the Yoruba is constantly changing, the threshold of the culture could not fit into the international style design. The style could not be used with local materials without having challenges with the micro climate of the building interior. The response of the people was to adopt parts of the style like the plain walls, glass on the facade and wider windows. The flat roof with parapet walls was not successful as it was fraught with technical and maintenance challenges. Low pitched roofs which were sometimes covered with parapets and roof gutters gave a semblance of the style but lost its appeal over time. The open floor design could only be used in commercial and institutional buildings. The residential houses did not adopt it as levels of privacy along family hierarchy could not be ensured in an open floor design. The vernacular arrangement of rooms around a central corridor was maintained in the buildings of indigenous architecture with some external features of the international style. Such an adaptation that blends with the culture of the people can still be classified as indigenous architecture of the Yoruba though it has progressed beyond the typical vernacular tradition.

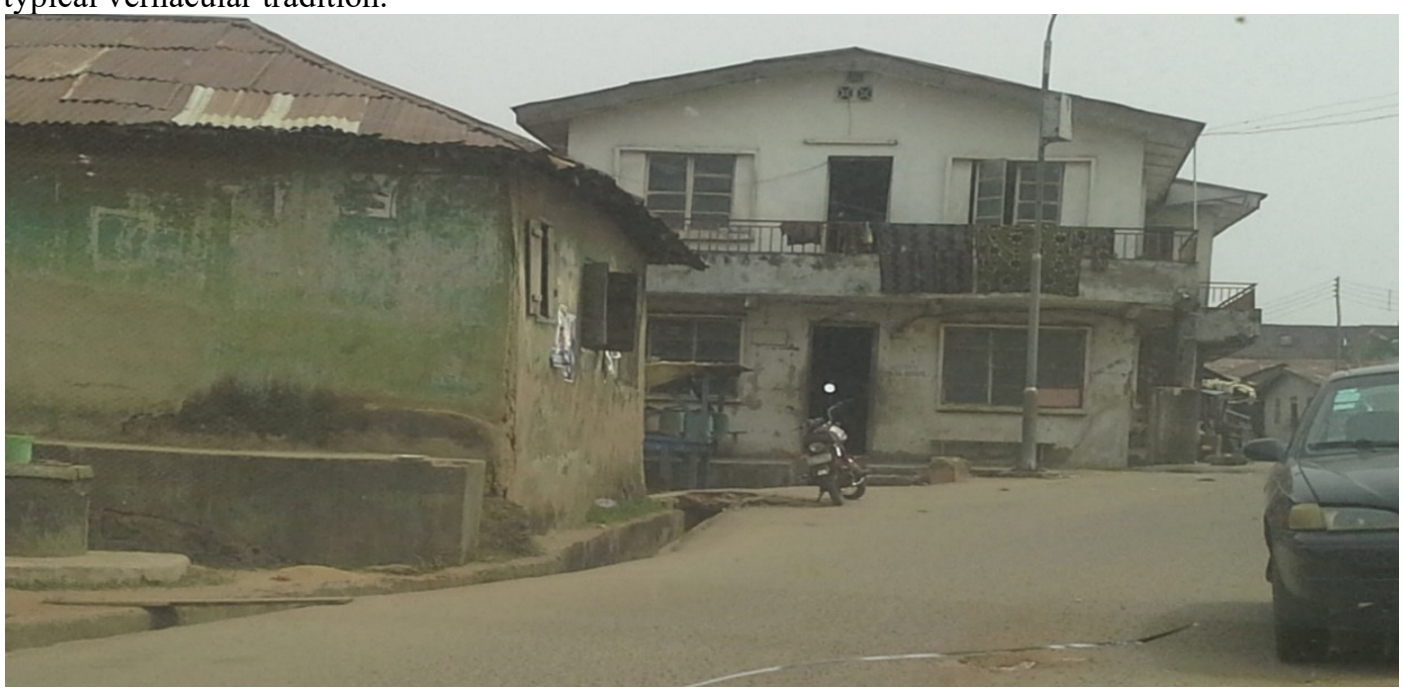

Traditional building beside an international style influenced vernacular building in Itoku area of Abeokuta, Southwest Nigeria

Source: Author (2019) 
Beyond the international style, the postmodern and contemporary styles of architecture are also present in the Yoruba towns. The styles which include deconstructivism, neo-classicism and high-tech architecture (Bullock, 2002) got introduced to the western world around the 1960s and became popular in Southwest Nigeria around the late 1980s. The lack of reverence towards individual cultures and formality of the modern architectural building style was finally upturned. Though some writers claimed it created an inroad for the return of eclecticism especially the neo-classic styles (Groat, 1982), the flexibility of the concept lends itself to better ethno-acculturation around the world. Literature on the adaptation of Yoruba architecture to accommodate the postmodern and contemporary styles are not very common. Discourses on buildings of postmodern styles are common but not in relation to the architecture of the Yoruba (Gitler, 2010). Other issues concerning construction methods, cost related issues and environmental impact assessments dominate such literature. Despite the apparent lack of materials on indigenous architecture of the Yoruba beyond the vernacular tradition, evidence of the postmodern inclinations of the basic indigenous architecture are common in the Yoruba settlements. The interior spatial organization remains the same but the exterior reflects aspects of postmodernism especially the neo-classicist style.

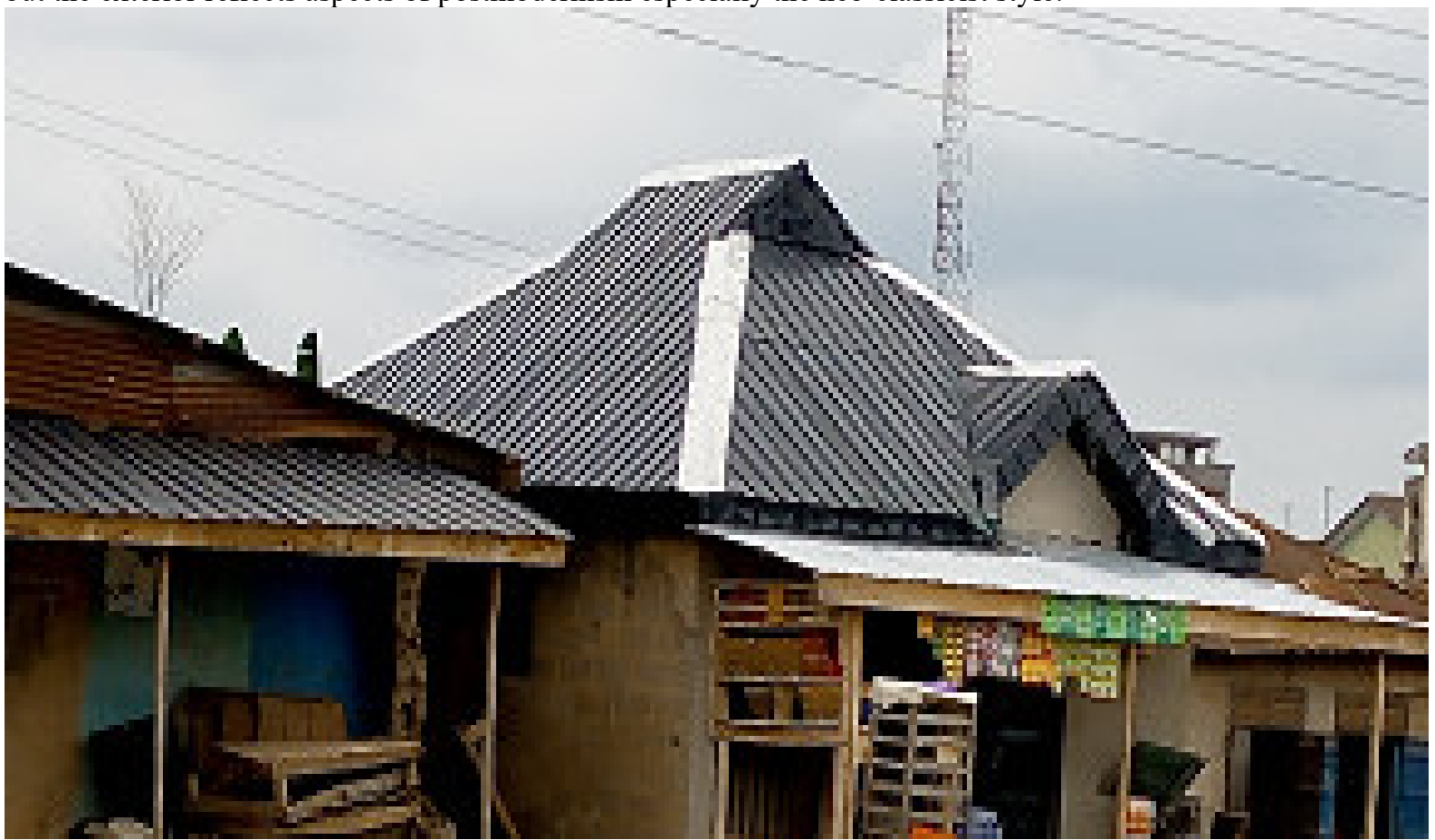

Contemporary roof forms on vernacular structures in Abeokuta city core of Southwest Nigeria

Source: Author (2019)

\section{CONCLUSION}

The indigenous architectural building morphology of the Yoruba has been properly documented for the earlier thresholds. These are in the realms of traditional architecture and vernacular architecture. Recent morphological thresholds of the indigenous architecture have not been defined and well documented. The academic circle of architects in universities and polytechnics of Southwest Nigeria who have played a larger role in the documentation need to go a bit further to decipher the subsequent morphological stages in the evolution and tag them properly for future discourse. The Yoruba have an evolving culture which reflects directly on their architecture. The current global situation of cultural cross-pollination and difficulty of attaching the new architectural styles to places has not brought the Yoruba architectural morphology to a surcease. It is still evolving with the dictates of the changing culture and can be documented.

\section{REFERENCES}

Adedokun, A. (2014). Incorporating traditional architecture into modern architecture: Case study of Yoruba traditional architecture. British Journal of Humanities and Social Sciences, 1(2), 30-45.

Adeokun, C. O. (2012). Analysis of spatial types and social space in Ile-Ife domestic architecture. Analysis of Spatial Types and Social Space in Ile-Ife Domestic Architecture, 1-16.

Adeokun, C. O. (2013). The Orowa House: A Typology of Traditional Yoruba Architecture in Ile-Ife, Nigeria.

Alonge, M. M. D., and Telford, M. M. D. (1994). Afro-Brazilian architecture in Lagos State: a case for conservation (Doctoral dissertation, Newcastle University).

Amole, B. (2000). Yoruba vernacular architecture as an open system. Legacy, 2(2), 63-72. 
Asiwaju, A. I. (1979). The Aja-speaking peoples of Nigeria: a note on their origins, settlement and cultural adaptation up to 1945 . Africa, 49(1), 15-28.

Asomani-Boateng, R. (2011). Borrowing from the past to sustain the present and the future: indigenous African urban forms, architecture, and sustainable urban development in contemporary Africa. Journal of Urbanism: International Research on Placemaking and Urban Sustainability, 4(3), 239-262.

Blier, S. P. (2006). Vernacular architecture. Handbook of material culture, 230-253.

Bullock, N. (2002). Building the post-war world: modern architecture and reconstruction in Britain. Psychology Press

Denyer, S. (1978). African traditional architecture: an historical and geographical perspective (No. 72 (6)). Heinemann.

Dmochowski, Z. R. (1990). An Introduction to Nigerian Traditional Architecture: South-West and Central Nigeria (Vol. 2). Ethnographica Limited.

Gharibpour, A. (2012). Definition of Architecture. International Journal of Architecture and Urban Development, 2(4), 51-58.

Gitler, N. I. B. A. (2010). Campus Architecture as Nation Building: Israeli architect Arieh Sharon's Obafemi Awolowo University Campus, Ile-Ife, Nigeria. In Third World Modernism (pp. 125-152). Routledge.

Groat, L. (1982). Meaning in post-modern architecture: An examination using the multiple sorting task. Journal of Environmental Psychology, 2(1), 3-22.

Hess, J. B. (2006). Art and architecture in postcolonial Africa. Jefferson, NC: McFarland.

Ilesanmi, A. O., and Egbe, M. (2013). Sustainable Innovations in Building Design: The Courtyard and Veranda Concepts in Nigeria. In AEI 2013: Building Solutions for Architectural Engineering (pp. 594-603).

Le Roux, H. (2004). Modern architecture in post-colonial Ghana and Nigeria. Architectural History, 47, 361-392.

Marafatto, M. (1983). Brazilian houses Nigeriane. Nigerian Brazilian houses.

Mihaila, M. (2014). City architecture as cultural ingredient. Procedia-Social and Behavioral Sciences, 149, 565569.

Noble, A. (2007). Traditional Buildings (Vol. 11). IB Tauris.

Obot, I. D. (2007). Sustainability in African architecture: Problems and prospects. In conference on African architecture today, Kwame Nkrumah University of Science and Technology, Kumasi, Ghana.

Ogunsote, O. O., and Prucnal-Ogunsote, B. (2002). Defining climatic zones for architectural design in Nigeria: a systematic delineation. Journal of Environmental Technology, 1(2), 1-14.

Oliver, P. (2007). Built to meet needs: cultural issues in vernacular architecture. Routledge.

Olotuah, A. O., and Ajenifujah, A. O. (2009). Architectural education and housing provision in Nigeria. CEBE Transactions, 6(1), 86-102.

Omokhodion, D. (1988). Benin in West African architecture. West African Journal of Archaeology, 18, 73-80.

Opoko, A. P. (2001). Low-energy Features of Traditional Buildings in the Hot-Dry Climatic Zone of Nigeria. NIA Journal, 11(8-12), 29-35.

Opoko, P. A., Adeokun, C. O., \& Oluwatayo, A. A. (2016). Influences on Artistic Expression in Traditional Domestic Architecture of South West Nigeria. International Journal of Applied Engineering Research, 11(6), 4548-4553.

Osasona, C. O. (2007). From traditional residential architecture to the vernacular: the Nigerian experience. Online http: www. Mainline. Org/aat/2007 documents/AAT Osasona, 17-19.

Osasona, C. O. (2012). Transformed culture, transforming builtscape: Experiences from Nigeria. International Journal of Sustainable Development and Planning, 7(1), 69-100.

Osasona, C. O., and Ewemade, F. O. (2010). The changing faces of the concrete balustrade in Nigerian vernacular architecture. WIT Transactions on Ecology and the Environment, 139, 395-409.

Osasona, C. O., \& Hyland, A. D. C. (2006). Colonial Architecture in Ile-Ife, Nigeria. Bookbuilders, Editions Africa.

Prucnal-Ogunsote, B. (2002). The International Style in Nigeria: Technological and Cultural Bridge-or Disaster. Journal of Environmental Technology, 1(1), 102-114.

Relph, E. (2016). The Modern Urban Landscape (Routledge Revivals). Routledge

Roux, H. L. (2004). Building on the boundary-modern architecture in the tropics. Social Identities, 10(4), 439453.

Uduku, O. (2006). Modernist architecture and 'the tropical'in West Africa: The tropical architecture movement in West Africa, 1948-1970. Habitat International, 30(3), 396-411.

Umoru-Oke, N. (2010). Risawe's Palace, Ilesa Nigeria: Traditional Yoruba Architecture as Socio-Cultural and Religious Symbols. African Research Review, 4(3).

Vlach, J. M. (1976). Affecting architecture of the Yoruba. African Arts, 48-99.

Vlach, J. M. (1984). The Brazilian house in Nigeria: the emergence of a 20th-century vernacular house type. The Journal of American Folklore, 97(383), 3-23. 